\title{
ミース・ファン・デル・ローエのフッベ邸とジェイ・ハンビッジの正方形分割 \\ THE PLAN OF HUBBE HOUSE BY MIES VAN DER ROHE AND THE SQUARE DIVIDED BY JAY HAMBIDGE
}

\author{
加治大 輔*, 近江 隆**, 石坂公一*** \\ Daisuke KAJI, Takashi OMI and Kouichi ISHIZAKA
}

\begin{abstract}
The purpose of this paper is to demonstrate that the works of Mies van der Rohe have similar geometrical characteristics to those in Jay Hambidge's theory, "Dynamic Symmetry". It has been said that there are squares and golden means in Mies' works. Some of his works were explained by compounding squares. In this paper, we analyzed the Hubbe House from a viewpoint of dividing the square geometrically, not compounding it. As a result, we found the proportion of the arrangements of its many elements identical to those in the square divided by Hambidge's method with irrational numbers. Although "Square" and "Golden rectangle" are old concepts and figures being used from ancient times, Hambidge. reconsidered them with biology and developed the original theory for beauty of proportion. The house is designed with the basic square form, but there is a modern geometrical beauty of Dynamic Symmetry in its shape.
\end{abstract}

Keywords: Mies, plan, Hambidge, geometry, proportion, modem architecture ミース、平面図、ハンビッジ、幾何学、プロポーション、近代建築

1. 序

筆者らは、これまでにミースの建築作品における平面に、それ と同時代のダイナミックシンメトリー理論に通底する幾何学的 形式が存在することを示唆し、そこに既往の論文とは異なる造形 原理を見出してきた 1)。具体的には、ジェイ・ハンビッジが一連 の著書 2に括いて系統立てた幾何学的分割や複合形態のうち、極 分割、対数螺旋、正方形とルート 5 矩形の 4 連形などがファンズ ワース邸や煉瓦造田園住宅の平面図に存在していることを指摘 した。ハンビッジの書においては図形の分割と複合に関して複数 のモデルが提示されているが、今回、ミ一スのドイツ時代の住宅 作品である「フッべ邸」平面図の背後に、既往のミース関連の論 文では扱われていないハンビッジの正方形分割に合致する図形 的特性が数多く存在することが判明したため、ミースの作品に内 在する正方形分割の展開として報告をするものである。

\section{2. フッベ邸平面図}

フッベ邸は、ミースの友人で画家であったエミール・ノルデの 知人マルガレーテ・フッベ夫人からミースが設計を依頼された住

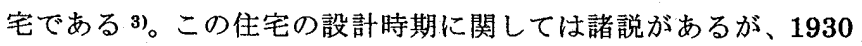
年代半ばにその設計が開始されている4)。建設予定地はマグデブ
ルグ近くのエルベ川の中州にあたる島であり、ミースによれば東 には絶景がひろがり、南側の風景は妨げられていて魅力のないも のであったという5)。この住宅の形態的特徴に関しては、ミース のドイツ時代における一連のコートハウス案との類似性が指摘 され6)、それらの実施案としての位置づけもなされており 7)、 本作品はミースのプロジェクトにおいて重要なものの一つであ る。フッベ邸の計画図とされているものとしては数種の案が存在 している。初期段階の分棟形式のもの、全体が L型に配置されて いるもの、凹凸が多い複雑な外形のもの、単純な矩形の中に殆ど の要素が納められた矩形型のものなどである8)。中でもコート(中 庭）を有する案のうちで、フリーハンドで粗く描かれたドローイ ングではなく、定規やコンパスによって線が引かれ躯体や開口の 位置まで確定している図面が存在するものには 2 種類の案があ る (Fig.1、Fig.2)。それらの外形は、一つが完全な正方形、他 方はやや長めの矩形であり、これらは案としては他に比べてより 終盤のものであるとされている9)。Fig.1、2はこれら 2 案に関す る複数のドローイングのうち、細部までが決定され、四面として 最も完成度の高いものである。これら単純な矩形に絵められた平 面にどのような幾何学的操作が隠れているのか、Fig.3 に示され たように、正方形の中に黄金矩形を書き込んだ分割が一つの壁の
* 東北大学大学院工学研究科都市建築学専攻 助手. 工修

** 東北大学大学院工学研究科都市建築学専攻 教授 - 工博

*** 東北大学大学院工学研究科都市建築学專攻 助教授 $\cdot$ 工博
Research Assoc., Dept. of Architecture, Graduate School of Engineering, Tohoku Univ., M. Eng.

Prof., Dept. of Architecture, Tohoku Univ., Dr. Eng.

Assoc. Prof., Dept. of Architecture, Tohoku Univ., Dr. Eng. 


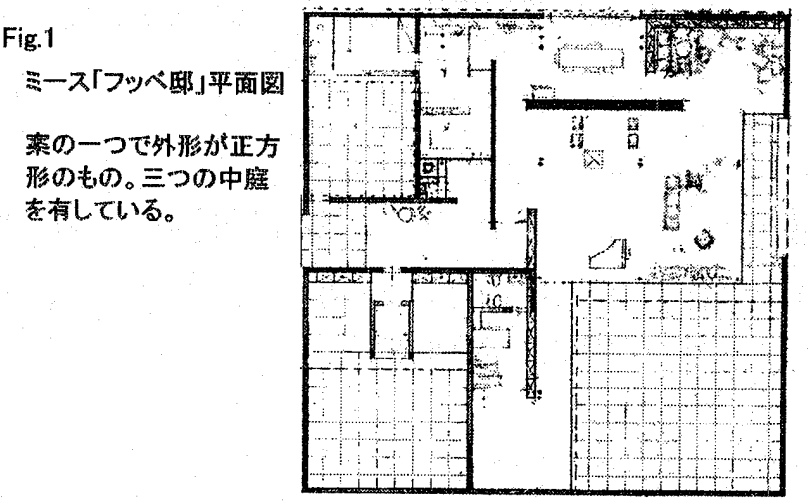

Fig. 2

ミース「フッベ邸」平面图

实のーつで外形が㩖方 形のもの。中庭索有し、 南面㐊開している点で はFig.1に共通している が、外形、空内隔壁の 配㯰などは理なる。
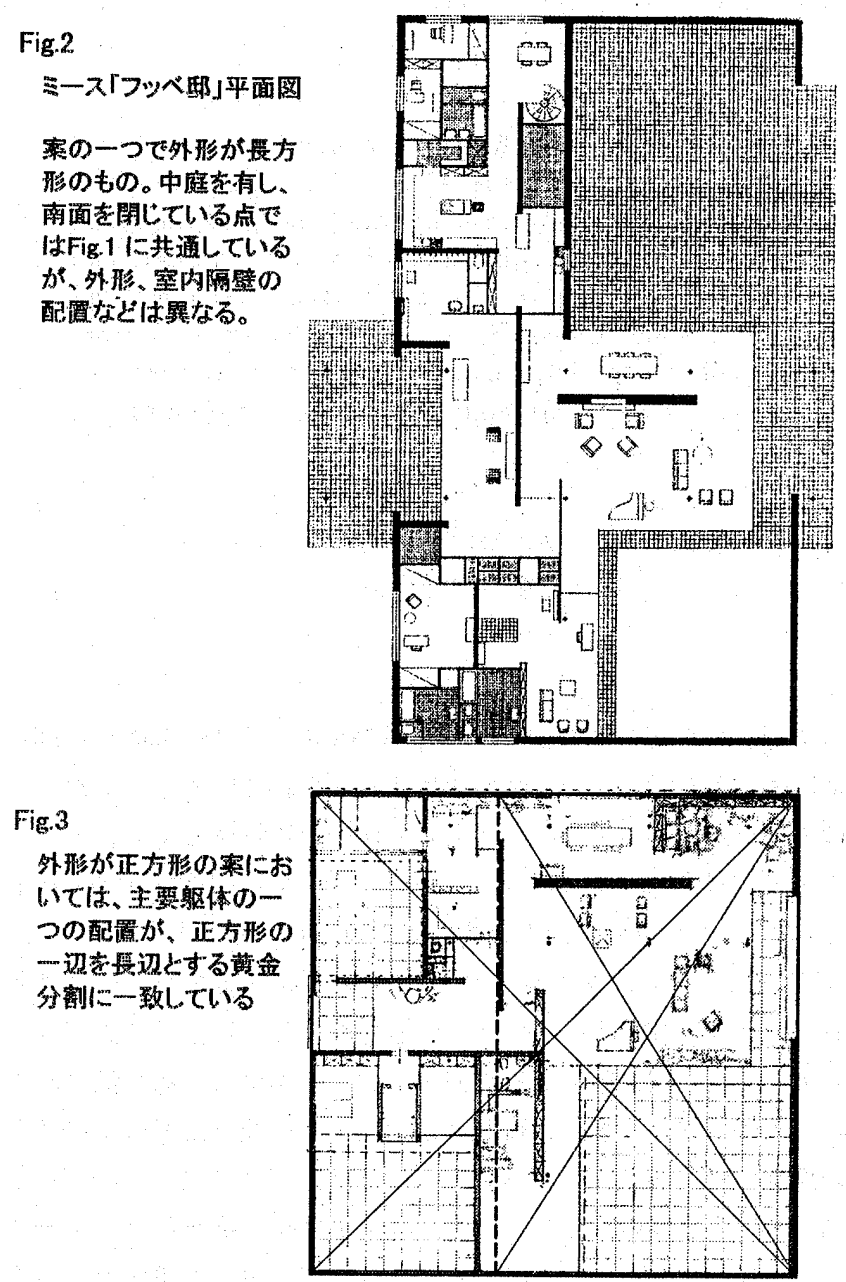

位置を決定しているかのように存在している一方で、正方形や黄 金比だけでは説明がつかない壁配置も多いことから、ダイナミッ クシンメトリー理論に着目して分析を試みる 10)。

\section{Dynamic Symmetry}

ダイナミックシンメトリー理論は、エール大学で教鞭を執って いたハンビッジが、ギリシアやエジプトの古代における芸術作品 のプロポーションが、生物学に見られる対数螺旋を基とした幾何 学的操作から生成される動的な形式に一致するものとして体系 化した比例理論である。彼の展開した美の理論においては、主に 円弧を用いてルート矩形 11)を導くこと、極分割によって対数螺旋
と矩形とを関係づけることを基本に幾何学的操作が行われ、無理 数による分割と複合のモデルを産出して行くところに特徽があ る 12)。なかでもハンビッジが提示した正方形の分割法には複数の モデルが存在しており、Fig.1 の平面外形が単純に正方形である ことに着目してこの分割法との関係を分析する。

\section{4. 分析}

ここで説明の便宜上、柱、壁、ガラス面などのエレメントのう ち呼称を必要とするものには各案に対して Fig.4、Fig.5に示すよ

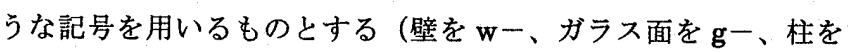
$\mathbf{p}$ 一とし、北北東を上として、方向に関しては「上」「下」「左」 「右」と乎び分けることとする）。まず、外形が正方形である Fig. 1をとりあげる。

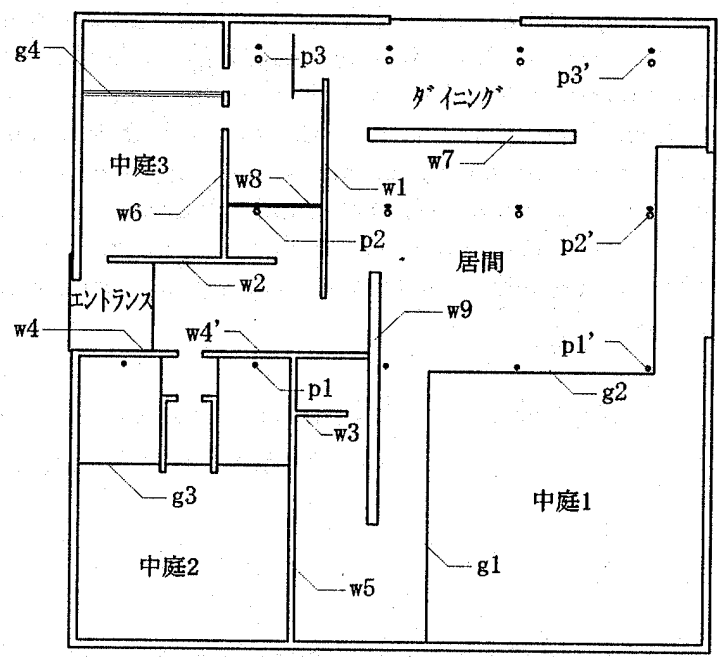

Fig.4 前揭Fig. 1察·主要エレメンントの記奇表示

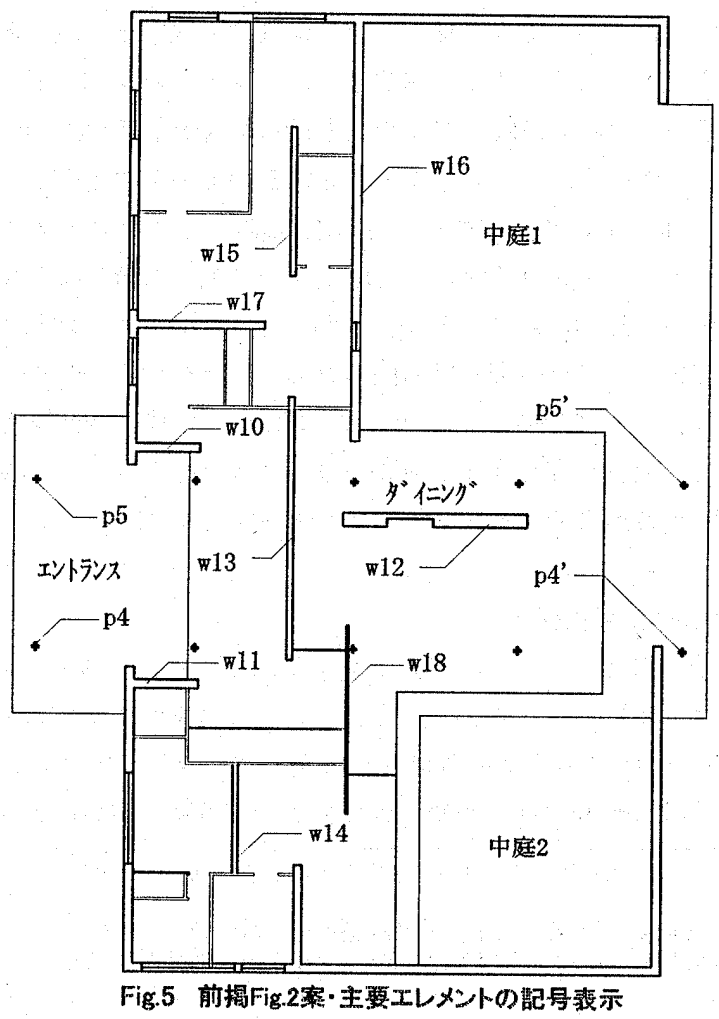


Fig.3のように正方形中にその一辺を長辺とする黄金矩形を生む 分割は、ダイナミックシンメトリー理論の基本的分割の一つであ る。ハンビッジの書にはその図法（Fig.6）やその応用で余白を 正方形々黄金矩形に分割した図（Fig. 7)，正方形の 3 辺に対し て Fig.6 の分割を施した図 (Fig.8) が図示されている。
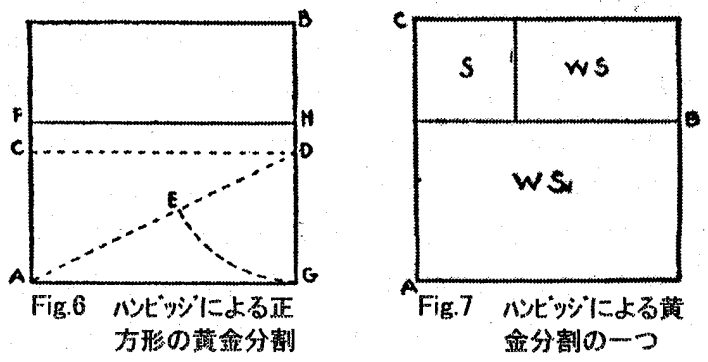

ハンビッジは、この分割によって古代エジプトのレリーフを解釈

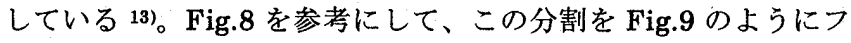
ッべ邸の平面図上に描き込むと居間に面している室内壁 w1、中 庭 3 とエントランスを隔てている壁 $\mathrm{w} 2$ 、衛生設備の隔壁である w3 などがこの線に接する（平面上における分割線の描画に関し ては、視覚的配慮から綐横の線を点線で図示し、斜線を実線とし た）。次に、ハンビッジの書において度々登場する基本的な正方 形分割として正方形の辺長 1 に対して、これを 0.4472 と 0.5528 の比に分割する方法がある（Fig.10）14)。彼はダイナミックシン メトリー理論の影響を受けた画家の一人である Christine Herter の絵画 “The Kneisel Quartet”をこの分割を用いて解説 している ${ }^{15) 。 こ の ~} 0.4472$ と 0.5528 の比による分割をフッべ邸 の平面に施したものが Fig.11 である 16)。すると、中庭 1 と室内 を隔てるガラス面 g1、柱 p1-p1'の位置を決定する柱芯が分割線 に一致する。ここで、ガラス面 $\mathrm{g} 2$ や室内壁 $\mathrm{w} 4 、 \mathrm{w} 4$ 'はこの柱芯 から僅かばかり離れる形で配されているが、建筑設計において施 工や見栄上、壁やガラス面を柱から引き離して配置することはご く自然に行われていることであり、g2や w4 は柱芯 p1-p1'を基に 布置されていると考えても矛盾はない。また、ハンビッジの書に おいて教示されている分割に、Fig.10に対して、正方形の対角線 と 0.5528 矩形 ${ }^{17)}$ の対角線の交点を利用したものがある(Fig.12) この分割により Fig.13 のように中庭 2 と室内を隔てる壁 w5、同 じく中庭 2 に面したガラス面 g3 が説明可能である 18)。さらに Fig.10における正方形分割の応用として Fig.14のような分割も ハンビッジの書に記載されている。これは、0.5528 矩形に対し て対角線 $\mathrm{AB}$ に直線 ED を直交させた極分割である。この分割を 平面に施し、交点に補助線を引いてみると Fig.15のようになり、

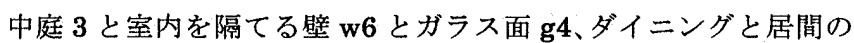
間の分厚い暖炉壁 19) w7 が分割線に接していることがわかる。 また、Fig.14における分割を、方向を変えて平面上に書き込み補 助線を記したものが Fig.16 である。これには衛生設備の間仕切 り w8 や p2-p2'の柱芯が一致する（w7、g4 は Fig.15 で説明済み である）。次に、説明がついていない室内壁 w9 であるが、これ は Fig.17のようにエントランスに面した壁 w4、w4’とによって 正方形を形成するように配置されているので、w4 を決定した Fig.10の分割に間接的に関係している ${ }^{20) 。 ~}$

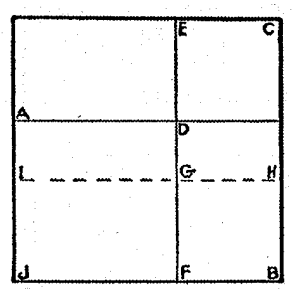

Fig.8(上) Fig.9(吕) ハンピッジによる正方形の 葓金分割(上)と、フッベ邱 の平面图上の関係

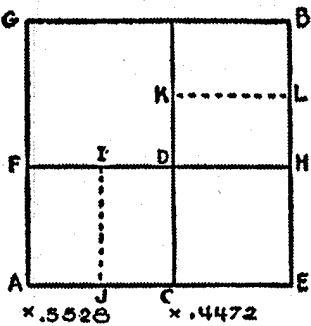

Fig.10(上) Fig.11(苜)

ハンビッジが元した 0.5528 0.4472 の分割（上）上、フッ ヘ哂の平面图の関係

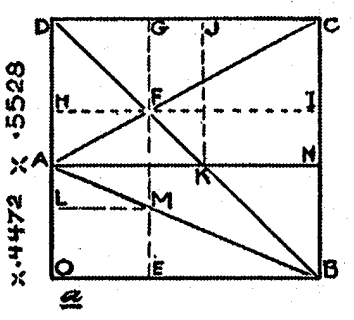

Fig.12(上) Fig.13(右) $0.5528 ， 0.4472$ 分割のハン ビッジによる庶用編（上） と、フッベ斯平面图の関係

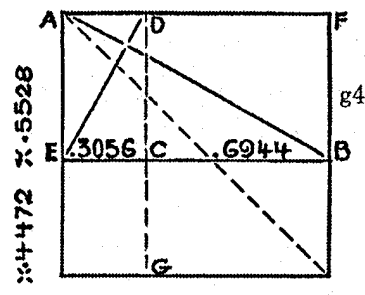

Fig.14(上) Fig.15(右) $0.5528 、 0.4472$ 分割 の ンビッシシによる応用編(上) とフッベ邸平面图の閣係
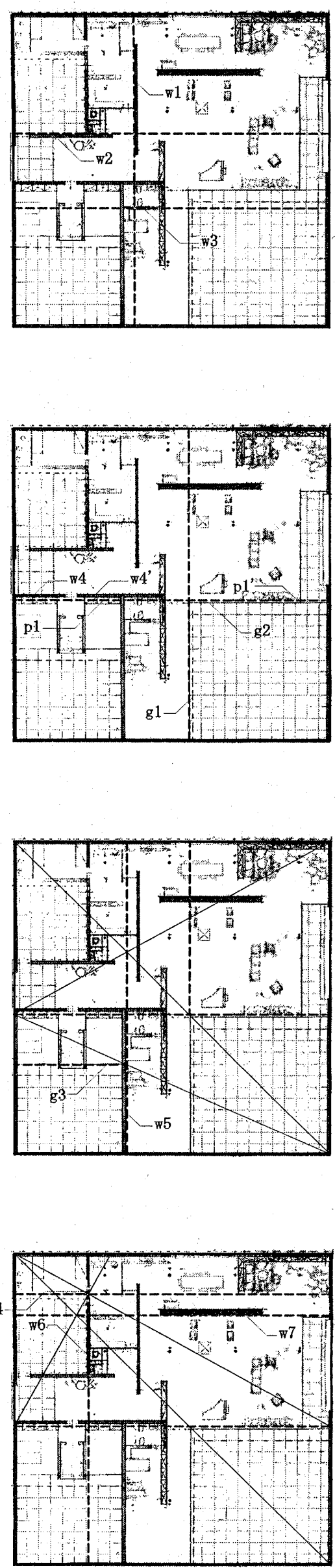
Fig.16 (右)

前睨Fig.14の正方形 分割を $90^{\circ}$ 回転させ て平面に施した图

Fig.17（右）

w9は, w4ட正方形を 形成するかたちて配 されている
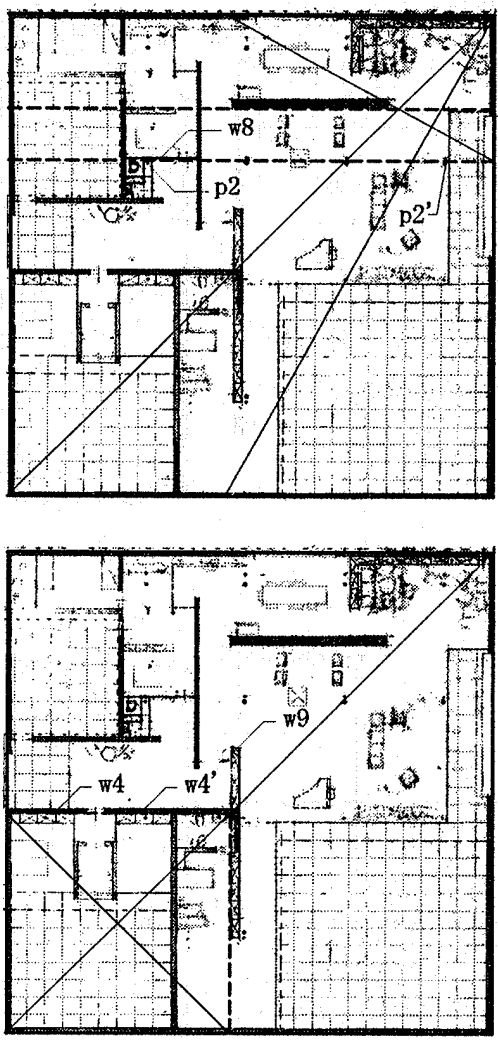

Fig.18（右）

p3-p3'における柱莈 のずれはp2-p2'の柱 淰のずれの2倍とな っている

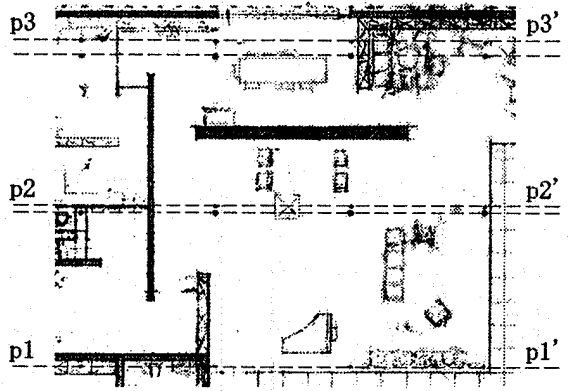

ここで、柱芯と基準線について言及しておきたい。Fig.11にお いて柱 p1-p1'を決定する柱芯が存在することを述べたが、Fig.1 を拡大寸ると、Fig.18 のように p2-p2、p3-p3’で柱が 2 本づつ、 その位置が少しずらされたように描かれている。つまり p2-p2'、 p3-p3’に於いては、柱芯の位置として二つの候補が存在したもの と考えることが出来る。しかも、二つの柱芯は p3-p3'での位置の 差が p2-p2'での差の 2 倍になっている。これらから推察されるこ とは

1）柱芯の位置に関して何らかの検討されるべき事項があった。

2) p1-p1’での柱のずれがないので柱芯 p1-p1'が基準であった。

3） p1-p1'の柱芯と p2-p2'の柱芯とのスパンを基にして柱 p3-p3’の柱芯が決定された。

ということである。以上は先の Fig.11 と Fig.16における柱芯に 関わる分析に全く矛盾しない。ただし、1)に関しては現存ドロー イングからでは、検討された内容やその根拠などを知ることは出 来ない。

さて、ここまでの分析からフッべ邸の正方形型の案 Fig.1 にお ける壁体やガラス面など、エレメントの位置の殆どはハンビッジ
の正方形分割に一致し、それらは意図的になされている印象を受 ける。これが Fig.1 のみに生じた偶発的なものに過ぎないのかど うか、長方形平面である Fig.2にも着目したい。まず、この平面 外形を計測すると、長辺と短辺の比は 1.82 となっている。実は、 この数字に近い矩形がハンビッジの書に存在する。ハンビッジは 基本的な分割から発展させた無理数の分割の一つに 1.809 (以下 桁略）という数值を上げ、これを辺の比とする矩形を「1.809 矩 形」と称している ${ }^{21 \%}$ 。しかも、Fig.19のように 1.809 矩形を正 方形と黄金矩形とによって構成する複合法も示している。補足で あるが 1.809 は 0.5528 の逆数、のまり短辺／長辺を逆にしただ けなのでこの矩形は Fig.10で登場した 0.5528 矩形と同じプロポ ーションである。試みに Fig.19 に従い Fig.20 のように 1.809 矩 形 (0.5528 矩形) をフッべ邸平面の Fig.2 に重ねてみると、エン トランス部分の袖壁 w10 が 1.809 矩形の正方形部分に接し、ま た正方形の対角線の交点を通る直線が中庭 2 の仕上材の境界線 に一致することがわかる。Fig.20に示すような正方形が内在する ことは設計過程のドローイング（Fig.21）からも判る。点線で囲 んだ正方形部分以外の上方に延びた部分に関しては外形しか描 かれていないにもかかわらず、正方形部分における内部の躯体配 置は大凡決定している。しかもその部分は Fig.1における中庭 2 の室内化や一部の壁配置の違いなど、差異はあるものの w7 や w9 をはじめとして Fig.1 の正方形平面に酷似したエレメントが 随所に見られるのである。つまり、Fig.2 の案は正方形平面であ る Fig.1 の案をもとに外壁を上側に延長させて発展させていった 可能性があり、その場合、幾何学的に正方形が内在することは必 然であると考えることが出来る。そこで、この Fig.2 の平面図に 関してもFig.1 と同様に正方形分割を用いた分析を行ってみたい。

まず、正方形部分に Fig.10における $0.5528 、 0.4472$ の分割を 施すと Fig.22 のよ5に、w10 に対峙するエントランス部分の袖 壁w11 や中庭 2 における仕上材の境界が分割線に接する。次に、 Fig.14に拐ける分割を施すと Fig.23 のようになり、居間とダイ ニングの間の暖炉壁 w12、エントランス正面の壁 w13、室内壁 w14 などが分割で得られた直線に接していることがわかる。また w15 はw13 の延長上にある。次に、ハンビッジの書には無理数 による正方形の分割として $\sqrt{2}$ を用いたものがある（Fig.24）。 これに内在する Fig.25 のような分割を 1.809 矩形において上側 に施したものが Fig.26である。すると、中庭 1 と室内を分け隔 てている境界壁 w16 と室内壁 w17 がこの分割に一致している。 また、w16 の延長上に w18 がある。ところで柱芯においても Fig.27 のように p4-p4'は Fig.6 の分割に一致し、これと w10の 位置関係を基淮にすると w11に対する p5-p5’が導かれる。

以上より、Fig.2 の案に扔ける多くのエレメントの配置は、

Fig.1の案と同様にハンビッジの正方形分割によって説明可能で あり、特に Fig.10 や Fig14 といった 0.5528 と 0.4472 の比の分 割やFig.6の黄金分割など共通する分割も存在することが判明し た。つまり、この 2 案は一見全く異なる形を有している印象を与 えるが、幾何学的には極めて近い関係にあることがわかる。とこ ろで、ハンビッジは随時その書において分割比を記しているため に数值から分割の位置を割り出せる場合も多いことに注意をし ておきたい。 


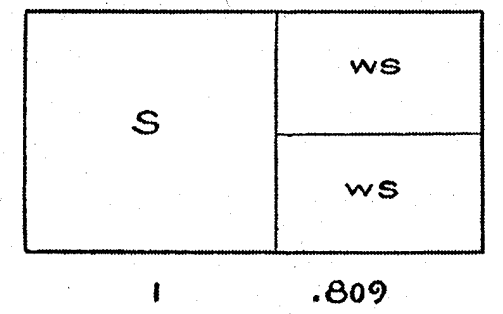

Fig.19(上、右)
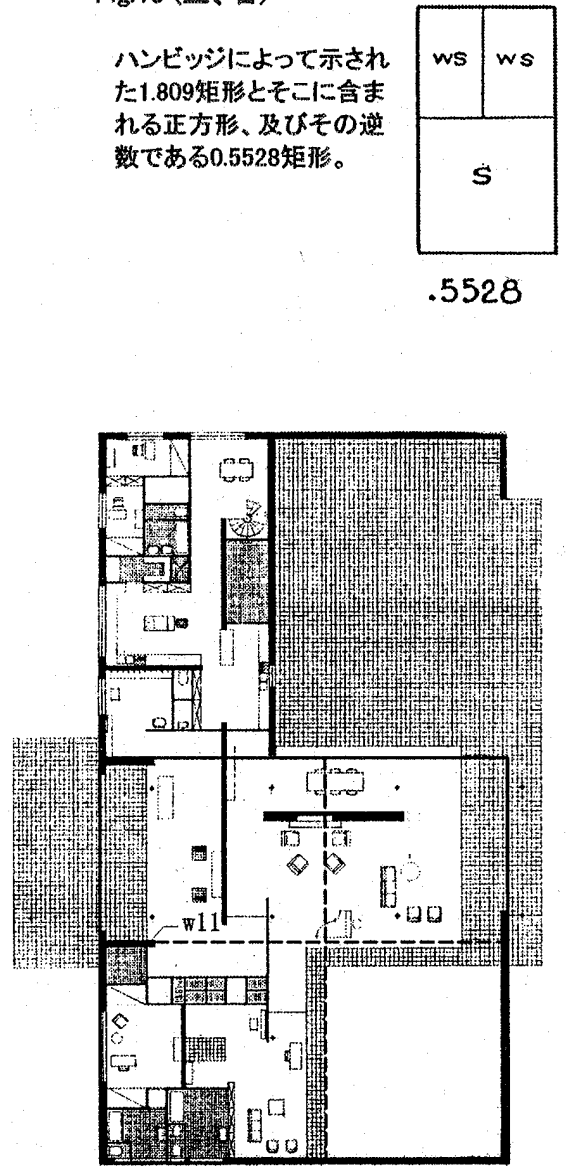

Fig.22 $0.4472,0.5528$ の分割と長方形平面

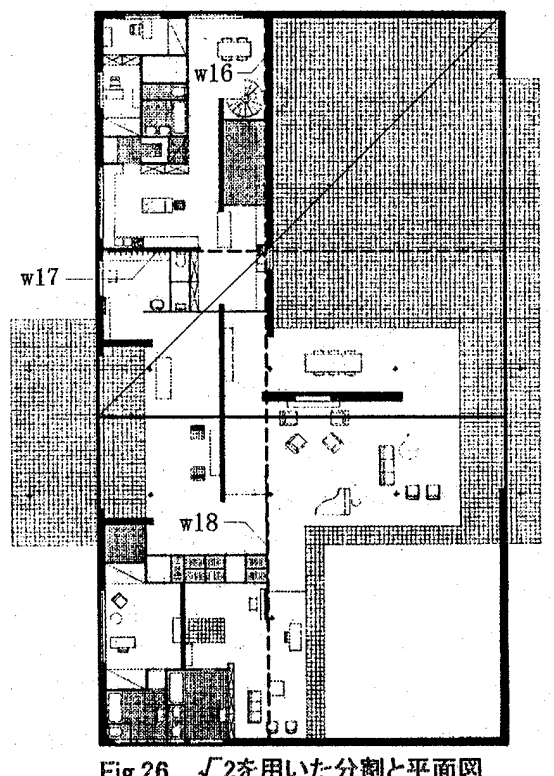

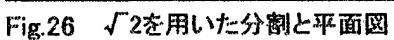
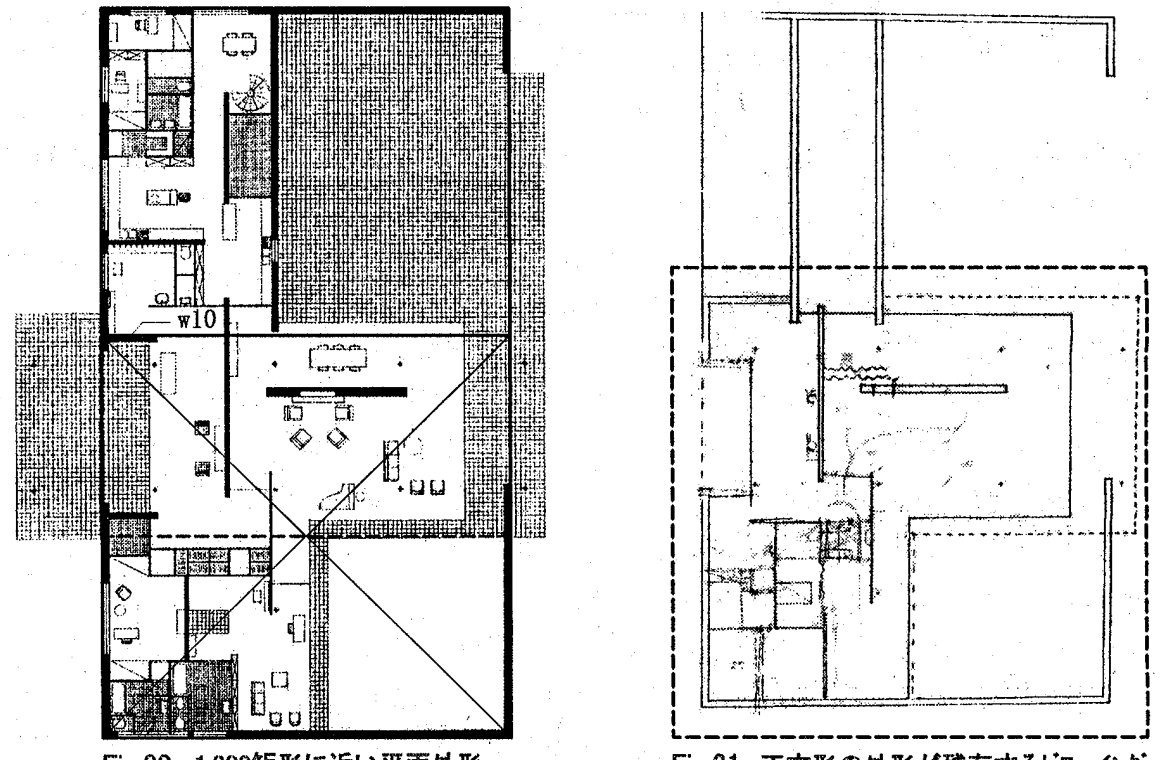

Fig.21 正方形の外形が惐存寸るドーイング

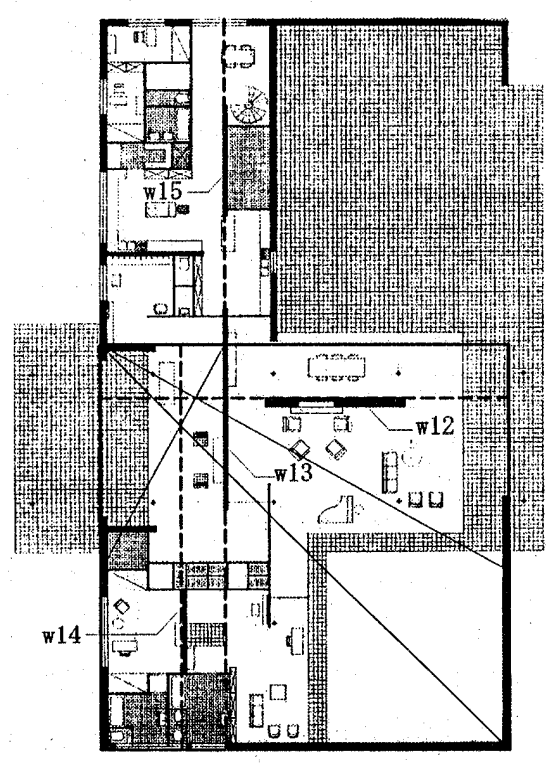

Fig.23 前揭Fig. 140分割と畏方形平面
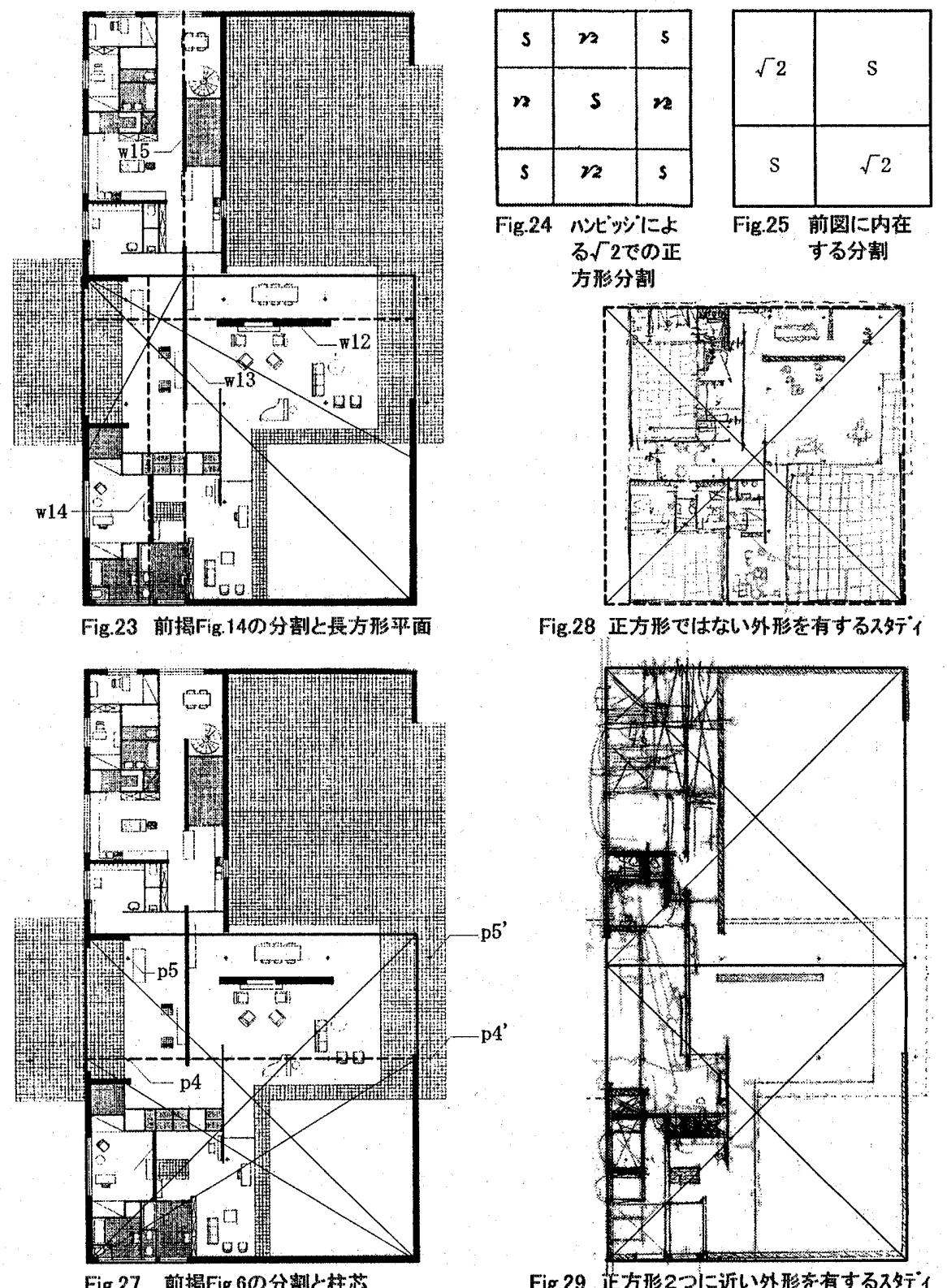

Fig.28 正方形ではない外形を有するス舛・

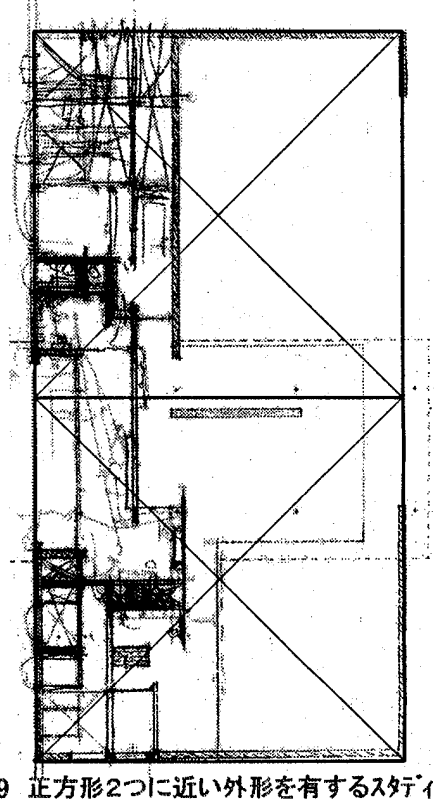


さて、このような厳密な幾何学的法則に合致するエレメントの 配置は、それ以前のスタディでは考虑されていたものなのであろ らか。例えば Fig.28 は Fig.1 のためのスタディの一つである。 殆ど Fig.1 に存在するエレメントを有している。言い換えると動 線や衛生設備、家具、間仕切りなど機能をサポートナるレヴェル においては大体 Fig.1 と同じである。しかし、プロポーションに ついて考えると外形は純粋な正方形ではなく、柱芯や壁も Fig.1 の位置とは若干ずれた位置にある。これは Fig.28 に類似した他 のドローイングに関しても言えることである 22)。

また、Fig.29 は Fig.2 に関するドローイングである。殆どの躯 体が出揃っているが、外形のプロポーションは正方形を二つ並べ たものに近く、1.809 矩形ではない。これらの事実は、ミースに とってある特定のプロポーションが絶対的なものとして最初に あるわけではない、ということを示している。しかし、それはミ 一スがプロポーションを軽視しているということと同義ではな い。これまでの分析から判明したように、最終的には殆どのエレ メントが特定の幾何学的法則に合致した配置となっている。つま り、ミースは、形態美を理由に各設計条件を犠牲にするのではな く、むしろ条件を充足するようにエレメントを用意しながら最終 的に幾何学にもとづいてプロポーションを整合させていると推 察されるのである。

\section{The Elements of Dynamic Symmetry}

ところで、今回の分析における分割パターンはいずれもハンビ ッジの書に揭載されているものであり、その図は複数の書に登場 するものもある 23)が、全ては “The Elements of Dynamic Symmetry”に収められているものである。つまり、この書一册 によってミースのフッベ邸の平面図 2 案におけるエレメントの 配置基準は説明されるのである。The Elements of Dynamic Symmetryは 1926 年に出版され、ハンビッジの他の書がギリシ アの壸や神殿のプロポーション、現代絵画の構図など、作品解析 に内容の大半が割かれているのとは異なり、本書は理論の基礎と 幾何学的分割パターンを中心として構成がなされている。もとも と、同書は 1919 年から 1920 年に至る冬にハンビッジがヨーロ ッパで発行していた月刊誌 “The Diagonal” から抜粋されたもの を集めたもの 24)で、その内容は大きく二つにわけることができる。 前半は自然界にみられる調和の法則にもとづいた簡単な分割に よる基礎的な矩形についてであり、後半は過去の研究を通じて得 られた複合矩形の紹介である。いずれも、実際の作品解析が登場 することはなく、図学的な操作や幾何学的図形が機械的に羅列さ れた構成となっている。つまり、The Elements of Dynamic Symmetry はハンビッジによる一連の書の中ではマニュアルの ような特化された内容となっているのである。ここで、本論で登 場した分割パターンの同書の中での位置づけについて (そこでは その数值的関係や幾何学的関係以上の意味は殆ど述心゙られてい ないものの）ハンビッジの記述を迻りながら考察しておきたい。 まず、Fig.6, 7, 8 についてである。それらは後半の応用編に揭載 されている図であるが、黄金分割は同書でも他のハンビッジの書 においても生物の成長に関わる比として理論全体の根拠となっ ている分割法であり、同様の分割法が同書の前半部の基礎的な矩
形群のひとつとして登場する 25)。次に、Fig.10 は同書の後半に おいて重要視されている分割（または複合）であり、後半部の最 初に紹介されている ${ }^{26)}$ 。そこでは、この分割で生成する 0.5528 といら值の逆数が 1.809 であることも記述されている。数比とし ては 0.4472 と 0.5528 は耳慣れない数字ではあるが、図学的には 註 14 で示したように正方形内部の黄金矩形を作図する過程で導 かれるものであり、本来ならば黄金比の背後に鿵れて存在してい る数值である。そして、ハンビッジは、この分割から Fig.12、 Fig.14 などをダイナミックシンメトリーの基本である極分割法 27)によって派生させている。次に Fig.24についてであるが、こ れは、前半の基礎的な矩形で紹介されている分割である。特にっ 2 から 5 までの $\sqrt{\mathrm{n}}$ 矩形は、ハンビッジの書においては基本的 な分割比であり、作図では、 2 は正方形から直接導かれる 28)。こ れらから判ることは、フッベ邸の分析で現れた正方形の分割は The Elements of Dynamic Symmetry のなかでも極めて基本的、 もしくは重要であるとされているものばかりである。ところで、 Fig.12 の分割と Fig.14 の分割とは分割線の位置が異なるために 結果としては全く異なる比を生じさせているように思われるが、

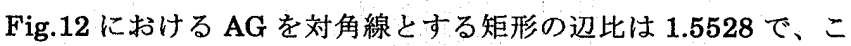
れは Fig.14における BG を対角線とする矩形の辺比に等しい。 このような、一見異なる分割であってもどこかに同じ比を生み出 すという幾何学と数字の魔術は、同書の全般にわたって貫かれて いる。これを建築のプロポーションと言う視点から解釈するのな らば、建物の各部分は「全体に対しての均整」を付与されるのみ ならず、異なる複数の分割からでも各部で同じような比例関係が 発生するという構造を生み出すことになる。

\section{6. 結語}

今回の分析を通じて、フッベ邸における主要壁体や柱の基準線、 ガラス面の位置などの多くのエレメントが、ハンビッジが示した 無理数の正方形の分割パターンに一致することがわかった。ミー スの作品に正方形自体が存在することや正方形が組み合わされ ているという事は既往研究で明らかにされてきた ${ }^{29) 。 し か し 、 そ ~}$ れらに加え本論でのフッべ邸の分析からは、ミースが正方形の内 部を如何に幾何学的に分割するかという課題にも拘っていたこ とが窥われる。ダイナミックシンメトリ一理論は理論上では黄金 比を根拠にし、正方形自体は、“dynamic” に対する “static”

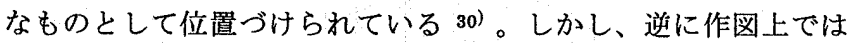
多くの矩形と同様に黄金矩形も正方形から導かれている。その意 味では正方形は同理諭書において、あらゆる図形の源泉となる特 別な形である。そして、ハンビッジもそうした正方形の位置づけ

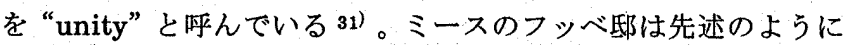
コートハウスの実施案と見なされているが、この時の外壁とは中 庭（コート）型を成立させるための前提であったはずである。そ うした外壁がフッべ邸においてはスタディの結果であったとし ても、ハンビッジの正方形と重ね合わせることができることは、 両者の捉えた形の意味において非常に興味哚い。そして、ここで のミースにとってのさまざまなエレメントとは、外壁を前提とし ながらも相互に微妙に関係し合うべき存在であったように感じ られる。 
時期的なものに触れるならば、1918 年から 1921 年にかけての ミースに関する記録は消失しており、それはミース自身によって 後に意図的に破棄されたともいわれている32)。そのため、この時 期に彼が The Diagonal を購読していたかどうかは定かではない。 しかし、上揭のようにフッべ邸におけるエレメントの配置はハン ビッジの正方形分割に一致する。ハンビッジが理論の展開の際に 用いた黄金比の数学的定義自体は古く、既にユークリッドによっ

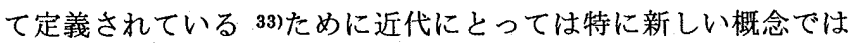
ない。また、正方形も建築形態においては近代建築に限らず古代 建築にも存在し、ルネサンス期には、人体の視覚的なプロポーシ ヨンや神学的アプローチなどから重要な造形のモティーフであ った。こうした意味では、黄金比や正方形は極めて古典的で伝統 的な概念や形態である。しかし、ハンビッジはこれら古典的な幾 何学の美の絶対性を A.H.チャーチの研究を基に生物学を援用す ることで解釈し再定義したのである。そして、それは結果的に無 理数による分割と複合のパターンを生成した。ミースの作品には、 古来より重用されてきた正方形や黄金分割が頻出するが、その一 方には、近代科学で普遍性を獲得しようとした 20 世紀初頭の美 学と同一の幾何学特性が内在しているのである。

\section{註}

1) 掘報

加治大輔、近江隆、石坂公一『ミースのファンズワース邸の平面に 潜むダイナミックシンメトリー』日本建築学会計画系論文集 第 535 号, 297-302, 2000 年 9 月

加治大輔、近江隆、石坂公一『ミース・ファン・デル・ローエ「煉 瓦造田園住宅案」に関する極分割法を用いた分析』日本建築学会計 画系論文集 第 544 号, 309-316, 2001 年 6 月

2) Jay Hambidge, Dynamic Symmetry The Greek Vase, Yale University Press, 1920

Jay Hambidge, Dynamic Symmetry in Composition as Used by The Artists, Yale University Press,1923 Jay Hambidge, The Parthenon and Other Greek Temples Their Dynamic Symmetry, Yale University Press,1924 Jay Hambidge, The Elements of Dynamic Symmetry,

New York Brentano's, 1926

3) Drexler, A, The Mies van der Rohe Archive, vol. 4, Garland pub, 1986 , p.220

Tegethoff, W, The Villas and Country House, trans by Stockman, R, MoMA, 1985, p121

4) Drexler は「おそらく 1934 年に設計が開始されたもの（Drexler, 1986, p220)」とし, Tegethoff も「1934 年に計画が始められたよ うである (Tegethoff, 1985, p121)」としているが、シュルツは 「1935 年の早いころ (Schultz. F, Mies van der Rohe A Critical Biography; 澤村明訳『評伝ミース・ファン・デル・ローエ』鹿島 出版会, 1987, p193)」、Cohenは1935 年にデザインされた(Cohen, J, Mies van der Rohe, trans by Stockman. E \& FN Spon, 1996, p73）」と述べるなど諸説がある。本論においては、これはハンビ ッジの理論の発表時期に関わるといった本質的問題ではないため、 「1930 年代半ば」とした。

5）敷地条件に関しては、ミースの記録 (Mies, “Haus H., Magdeburg,” Die Schildgenossen 14, 1935, pp.514-515）が存在するため、研究 者による見解の相違はみられない。

6) Drexler, 1986, p220

Tegethoff, 1985, p122

7) Cohen, 1996, p73

8) Drexler, 1986, pp240-481

9) Drexler, 1986, p220
10）他のドローイングにおいてタイル目地が区々である（Drexler, 1986, pp323-333）ことから、外形は目地割りのモジュールを用い て導かれたものではないと判断できよう。

11）ハンビッジは辺の比が $1: \sqrt{\mathrm{n}}$ であらわされるものを「ルート矩形」 と呼んでいる。但し、ハンビッジは古代ギリシア芸術においては が 5 より大きいものは殆どありえないとし、実際に彼の理論書にお いては、 5 までの表記しかない。

12）建築家アルベルティやパラーディオの書における $1: \sqrt{2}$ の比など 前近代の理論や建築にも無理数が存在するが、彼らが提呾していた のは有理数による比が主である。一方、ハンビッジも正方形を多用 するため、その理論には正数比も存在するが、無理数の比例バリエ ーションを主として生み出したところに彼の比例美の理論として の特性がある。ただし、ハンビッジの註 2 の文献において無理数は、 小数点下 4 桁で約されている。

$0.4472(\sqrt{5}$ 矩形 $)$ が存在する分割と複合

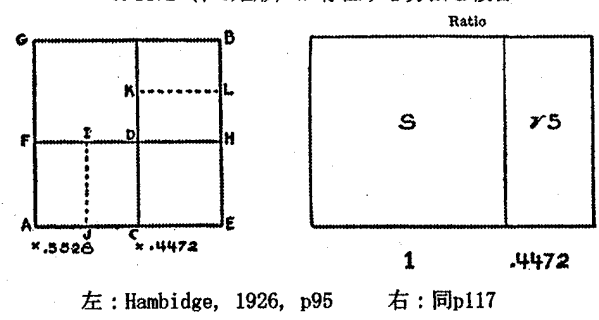

13) Hambidge, $1920, \mathrm{pp} 25-28$

14)幾何学的に 0.4472 と 0.5528 の比に正方形を分割するには 右図のように Fig.6 を利用す る。

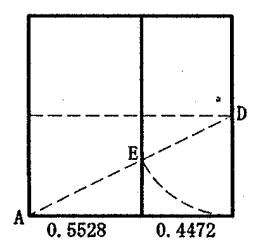

15) Hambidge, 1923, p10

16）この時、Fig.10の点線部分に関しては平面図と関係がなく、実線 部分のみを表示した。

17） ハンビッジは、矩形の㭔称について 2 辺の比を冠して「0.5528 矩 形」、「1.809 矩形」などと呼んでいる。

18） Fig.12における線分 JKが示す位置はFig.11でのガラス面 $\mathrm{g} 2$ で解 説済であり、線分 HIに関しては、該当するエレメントは存在しな い。

19）この案のみでは暖炉があるようには思われないが、Fig.2 や他の案 において居間とダイニングとの間には暖炬があるので、Fig. 5 にお ける w7 も暖炉壁であると推察される。

20）対角線を利用して相似形を描く方法恃にハンビッジによるもの ではないが、ハンビッジはその幾つかのパターンを著書において紹 介している。 (Hambidge, 1926, pp69-73)

21) Hambidge, 1926, p96

22) Drexler, 1986, pp332-333

23）例えば、Fig.24は Hambidge, 1926, p45 と Hambidge, 1920, p29 に揭載されている。

24) Hambidge, 1926, pv

25) Hambidge, 1926, p60

26） Hambidge, 1926, pp78-82、作図は註 14 参照。

27）加治、近江、石坂, 2001 年 6 月, p310

28) Hambidge, 1926, p22

29）佐野潤一『ミース・ファン・デル・ローエの三つの中庭をもつコー ト・ハウスの設計過程における回転正方形出現の経緯について』日 本建築学会計画系論文集 第 465 号, 189-195, 1994 年 11 月

藤井伸介、小林克弘、中原まり『ミース・ファン・デル・ローエの レンガ造田園住宅案における幾何学構成』日本建築学会計画系論文 集第 493 号, 231-236, 1997 年 3 月

佐野潤一『ミース・ファン・デル・ローエによるレイク・ショア・ ドライブ・アパートメントのファサードのプロポーションにおける 
ダブルスクエアと黄金比』日本建築学会計画系論文集：第 537 号, 319-324, 2000年 11 月

30) Hambidge, 1926, pxv

31) Hambidge, 1926, pp21-22

32）フランツ・シュルツは、これをミースの助手の証言から「モダニズ ムを受け入れたことの歴史的印象を単純にしょうとする試みり記 述している。（Schultz. F, Mies van der Rohe；澤村明訳, 鹿島出 版会, 1987, p83)

33) Fishler, R, A Mathematical History of the Golden Number, Dover pub, 1998, p12

\section{図版出典}

Fig. 1 : Drexler, 1986, p287より

Fig. 2 : Drexler, 1986, p240より

Fig. 3、9、11、13、15、16、17: Fig. 1 に筆者加筆
Fig. 4、5：筆者作図

Fig. 6 : Hambidge, 1926, p93 より

Fig. 7 : Hambidge, 1926, p92 より

Fig. 8 : Hambidge, 1926, p84より

Fig. 10 : Hambidge, 1926, p95より

Fig. 12 : Hambidge, 1926, p81より

Fig. 14 : Hambidge, 1926, p82 より

Fig. 18 : Fig. 1 をもとに筆者加筆

Fig. 19 : Hambidge, 1926, p117 より

Fig. 20、22、23、26、27：Fig. 2 に筆者加筆

Fig. 21 : Drexler, 1986, p246 をもとに筆者加筆

Fig. 24 : Hambidge, 1926, p45より

Fig. 25 : 筆者作図

Fig. 28 : Drexler, 1986, p330をもとに筆者加筆

Fig. 29 : Drexler, 1986, p244 をもとに筆者加筆 